\title{
Allometry of diet selectivity in juvenile Atlantic salmon (Salmo salar) ${ }^{1}$
}

\author{
Ernest R. Keeley and James W.A. Grant
}

\begin{abstract}
Juvenile salmonids in streams typically feed on larger invertebrates than the average size available in the drift. Our objective was to describe the allometry of this size-selective foraging in juvenile Atlantic salmon, Salmo salar of Catamaran Brook, New Brunswick. We compared paired samples of the stomach contents of 46 salmon (age 0+ to 2+; fork length $2.9-14.5 \mathrm{~cm}$ ) with drift samples collected from their feeding territories. Juvenile salmon fed opportunistically on all major types of invertebrates in the drift, except for water mites (Hydracarina). However, newly emerged salmon fed on smaller prey than the average available in the drift, primarily chironomid larvae, whereas salmon larger than $4.6 \mathrm{~cm}$ fed on larger prey than average, primarily dipteran adults and pupae. Larger salmon ate larger prey. Minimum prey length in stomachs was well predicted by gill raker spacing, but mean prey width was only one third of the optimal size and maximum prey width was much less than mouth width. The allometry of prey size appeared to be related primarily to an increase in size-selective foraging with increasing body size, rather than to morphological constraints. Juvenile Atlantic salmon in our study ate smaller prey than similar-sized salmonids in other studies.
\end{abstract}

\begin{abstract}
Résumé : Les salmonidés juvéniles dans les cours d'eau se nourrissent typiquement d'invertébrés de taille plus grande que la taille moyenne disponible dans la dérive. Notre objectif était de décrire cette allométrie dans ce broutage sélectif en fonction de la taille chez le saumon atlantique juvénile (Salmo salar) du ruisseau Catamaran, au Nouveau-Brunswick. Nous avons comparé des échantillons variés de contenu stomacal de 46 saumons (âge $0+$ à 2+; longueur à la fourche 2,9-14,5 cm) avec des échantillons de dérive prélevés dans leur territoire d'alimentation. Le saumon juvénile s'alimente de manière opportuniste de tous les principaux types d'invertébrés présents dans la dérive, à l'exception des hydrachnes (Hydracarina). Toutefois, les saumons nouvellement émergés s'alimentaient de proies dont la taille était plus petite que la taille moyenne des organismes disponibles dans la dérive, principalement des larves de chironomidés, tandis que les saumons de taille supérieure à 4,6 cm prélevaient des proies de taille plus grande que la moyenne, principalement des adultes et des pupes de diptères. Les saumons de plus grande taille consommaient des proies de plus grande taille. La longueur minimale des proies dans les estomacs pouvait être prédite efficacement par l'espacement du peigne branchial, mais la largeur moyenne des proies n'était que le tiers de la taille optimale et la largeur maximale des proies était de beaucoup inférieure à la largeur de la bouche. L'allométrie touchant la taille des proies semble être liée principalement à une augmentation du broutage sélectif en fonction de la taille, plutôt qu'à des contraintes morphologiques. Les saumons atlantiques juvéniles de notre étude ont consommé des proies plus petites que celles qui étaient consommées par des salmonidés de taille semblable dans d'autres études.

[Traduit par la Rédaction]
\end{abstract}

\section{Introduction}

Stream-dwelling salmonids feed primarily on drift, invertebrates carried by water currents (McNicol et al. 1985; Keeley and Grant 1995; but see Tippets and Moyle 1978). Diet selectivity in salmonid fishes has often been studied by comparing the invertebrates found in stomach samples with those found in drift samples. Such studies have shown that stream-dwelling salmonids feed opportunistically on a wide variety of prey types; there is usually a positive correlation between the proportions of invertebrates in the diet and in the drift (Allen 1941;

Received July 29, 1996. Accepted February 12, 1997.

$\mathrm{J} 13580$

E.R. Keeley ${ }^{2}$ and J.W.A. Grant. Department of Biology, Concordia University, 1455 de Maisonneuve Blvd. West, Montreal, QUE H3G 1M8, Canada.

1 Contribution No. 26 of the Catamaran Brook Habitat Research Project.

2 Author to whom all correspondence should be sent at the following address: Department of Zoology, The University of British Columbia, 6270 University Boulevard, Vancouver, BC V6T 1Z4, Canada. e-mail: keeley@zoology.ubc.ca
Allan 1981, 1995; Angradi and Griffith 1990). However, residual variation about this relationship is usually related to invertebrate size such that large invertebrates are usually over-represented in the diet, whereas small invertebrates are under-represented (Allan 1981).

The diet of fishes often change continuously with body size (Werner and Gilliam 1984). The few allometric studies of diet in stream-dwelling salmonids have documented an increase in prey size with body size (Fahy 1980; Rose 1986), perhaps because they become increasingly size selective as they grow larger (Newman and Waters 1984; Grant and Noakes 1986). However, no study has yet described how diet selectivity changes continuously with changes in body size.

Functional reasons for changes in diet and (or) selectivity with body size have been linked to morphological constraints and to feeding energetics. Minimum prey length is thought to be limited by gill raker spacing (Wańkowski 1979; Dunbrack and Dill 1983), whereas maximum prey width is thought to be limited by mouth width (Wańkowski 1979). Both gill raker spacing and mouth size increase with body size (Wańkowski 1979). Within the range of prey sizes set by morphological constraints, fishes are expected to select prey to maximize their energetic gain per unit time (Werner and Hall 1974). Because 
Table 1. Environmental correlates (Pearson product-moment correlation) of the number (number $\cdot \mathrm{m}^{-2} \cdot \mathrm{h}^{-1}$ ) and mean width $(\mathrm{mm})$ of invertebrates captured in 46 drift samples.

\begin{tabular}{|c|c|c|c|c|c|c|}
\hline \multirow[b]{2}{*}{ Environmental variable ${ }^{a}$} & \multirow[b]{2}{*}{ Mean } & \multirow[b]{2}{*}{ Range } & \multicolumn{2}{|c|}{ Number } & \multicolumn{2}{|c|}{ Width } \\
\hline & & & $r$ & Partial $r^{b}$ & $r$ & Partial $r^{b}$ \\
\hline Current velocity $\left(\mathrm{cm} \cdot \mathrm{s}^{-1}\right)$ & 21.0 & $1-45$ & $0.52 * *$ & $0.65 * *$ & 0.045 & 0.13 \\
\hline Water depth $(\mathrm{cm})$ & 31.5 & $4.0-67.3$ & $0.30 *$ & $0.48 *$ & -0.14 & -0.092 \\
\hline Substrate size ${ }^{c}$ & 3.1 & $2.0-4.1$ & $0.29 *$ & 0.057 & -0.067 & -0.041 \\
\hline Day of the year & 213.5 & $167-244$ & $-0.33 *$ & $-0.72 * *$ & -0.12 & -0.071 \\
\hline Fish length $(\mathrm{cm})^{d}$ & 6.4 & $2.9-14.5$ & 0.24 & -0.096 & -0.092 & -0.002 \\
\hline
\end{tabular}

Note: $* P \leq 0.05 ; * * P \leq 0.01$.

${ }^{a}$ Correlations are based on $\log _{10}$-transformed data for current velocity, water depth, prey numbers, and prey width.

${ }^{b}$ Correlation coefficient of an environmental variable versus the residual variation from a multiple correlation including all other environmental variables.

${ }^{c}$ Categorized according to Bain et al. (1985).

${ }^{d}$ Length of fish occupying the territory in which the drift sample was taken.

Table 2. Environmental correlates (Pearson product-moment correlation) of the number and width $(\mathrm{mm})$ of prey in the stomachs of 46 juvenile Atlantic salmon.

\begin{tabular}{lcclcc}
\hline \multirow{2}{*}{$\begin{array}{l}\text { Environmental } \\
\text { variable }^{\mathrm{a}}\end{array}$} & \multicolumn{2}{c}{ Number } & & \multicolumn{2}{c}{ Width } \\
\cline { 2 - 3 } \cline { 5 - 6 } Current velocity & -0.097 & Partial $r$ & & $r$ & Partial $r$ \\
Water depth & 0.26 & 0.04 & & $0.32^{*}$ & -0.041 \\
Substrate size & -0.13 & -0.14 & & $0.58^{* *}$ & $0.18 *$ \\
Day of the year & $0.31^{*}$ & 0.20 & & 0.21 & 0.12 \\
Fish length & -0.13 & -0.22 & & $0.78^{* *}$ & 0.16 \\
\hline
\end{tabular}

Note: $* P \leq 0.05 ; * * P \leq 0.01$

${ }^{a}$ Units and footnotes are as in Table 1.

larger fishes can handle prey of a given size more quickly than smaller fishes, optimal prey size is expected to increase with body size (Wańkowski 1979; Bannon and Ringler 1986).

Although the diet of juvenile Atlantic salmon has been extensively studied (Allen 1941; Egglishaw 1967; Lillehammer 1973; Wańkowski 1979; Williams 1981; Thonney and Gibson 1989; Cunjak 1992), no study has yet described the allometry of diet for a wide range of body sizes. We collected drift samples and stomach samples of juvenile salmon, $2.9-14.5 \mathrm{~cm}$ long, to describe the allometry of diet and diet selectivity. In addition, we determined whether changes in diet with body size could be best explained by morphological constraints or by models of optimal prey size.

\section{Materials and methods}

\section{Study site and species}

Data were collected from 15 June to 1 September 1992 at Catamaran Brook, a third-order tributary of the Little Southwest Miramichi River $\left(46^{\circ} 52.7^{\prime} \mathrm{N}, 66^{\circ} 06.0^{\prime} \mathrm{W}\right)$ in central New Brunswick. We captured fish in the lower $2 \mathrm{~km}$ of the brook and in a $1-\mathrm{km}$ section, $5 \mathrm{~km}$ upstream from the mouth of the brook. Adult Atlantic salmon return to spawn in the stream from mid-October to mid-November each fall. Youngof-the-year salmon emerge by mid-June at about $2.6 \mathrm{~cm}$ in length (Randall 1982) and remain in the stream until they are 2-3 years of age or $12 \mathrm{~cm}$ in length (Cunjak et al. 1993). A more detailed description of the stream and its biota can be found in Cunjak et al. (1990, 1993).

We collected 46 juvenile Atlantic salmon that we had individually observed as part of a study on territoriality (see Keeley and Grant 1995). The fish were captured by angling or by using two aquarium
Table 3. $\log _{10}$ prey size $(\mathrm{mm})$ versus $\log _{10}$ fork length $(\mathrm{cm})$ for 46 juvenile Atlantic salmon.

\begin{tabular}{llccc}
\hline Dependent variable & Slope & $Y$ intercept & $r^{2}$ & $P$ value \\
\hline $\begin{array}{lllll}\text { Prey width } \\
\quad\end{array}$ & & & \\
$\quad$ Mean & 1.042 & -1.11 & 0.61 & $<0.001$ \\
$\quad$ Maximum & 1.16 & -0.77 & 0.60 & $<0.001$ \\
$\quad$ Minimum & 0.79 & -1.35 & 0.43 & $<0.001$ \\
$\begin{array}{l}\text { Prey length } \\
\quad \text { Mean }\end{array}$ & & & & \\
$\quad$ Maximum & 0.64 & -0.068 & 0.60 & $<0.001$ \\
$\quad$ Minimum & 0.85 & 0.039 & 0.60 & $<0.001$ \\
& 0.37 & -0.25 & 0.08 & $=0.065$ \\
\hline
\end{tabular}

dipnets immediately following our observations, all of which were between 09:00 and 16:00. After observing an individual fish, we weighed $( \pm 0.05 \mathrm{~g})$, measured fork length to the nearest $0.5 \mathrm{~mm}$, and preserved it in $10 \%$ buffered formalin. We collected 26,12 , and 8 salmon of age $0+$ (fork length $2.9-5.1 \mathrm{~cm}), 1+(6.3-9.5 \mathrm{~cm})$, and $2+$ (10.3-14.5 cm), respectively (see Keeley and Grant 1995).

We later used a dissecting microscope, fitted with an ocular micrometer, to identify, count, and measure intact prey items in the esophogus and stomach. Prey items were identified to the order or family level using keys in Merritt and Cummins (1984) or Pennak (1978). Maximum prey length and width $( \pm 0.01 \mathrm{~mm})$ were measured for each prey item.

\section{Environmental variables}

Within $1.5 \mathrm{~h}$ of capturing an individual fish, we sampled food availability on its territory. Because almost $99 \%$ of foraging attempts are directed towards items drifting within the water column (Keeley and Grant 1995), we sampled food with a drift net $(15.2 \mathrm{~cm}$ wide $\times 23 \mathrm{~cm}$ high $\times 100 \mathrm{~cm}$ long, mesh size $300 \mu \mathrm{m}$ ) for $1 \mathrm{~h}$. The mouth of the drift net was constructed with a rectangular metal collar, that was $12.5 \mathrm{~cm}$ deep, to maintain a laminar flow at the mouth of the net and to prevent back-washing (see Field-Dodgson 1985).

Each drift sample was transferred to a holding jar for sorting that evening or the next morning. Inedible material, such as decomposing leaves and insect exuviae, was removed from the sample before preservation in $10 \%$ buffered formalin. Animals in the drift were identified and measured in the same manner as described for stomach contents. We then dried each sample in an oven at $50^{\circ} \mathrm{C}$ for $24 \mathrm{~h}$ before moving them to a desiccator for an additional $24 \mathrm{~h}$. The dry mass of each sample was determined at $24 \mathrm{~h}$ intervals until a stable mass $( \pm 0.0002 \mathrm{~g})$ was obtained.

Using a Marsh-McBirney meter, we measured current velocity at each fish's primary holding station (see Keeley and Grant 1995), the 
Fig. 1. Taxonomic composition (\%) of invertebrates in (a) drift samples (5210 organisms in 46 samples) and (b) stomach samples (1287 organisms in 46 stomachs) of juvenile Atlantic salmon. Chironomidae refers to larval chironomids only, whereas Dipteran adults and pupae includes chironomids as well as other dipterans.

\section{(a) drift}

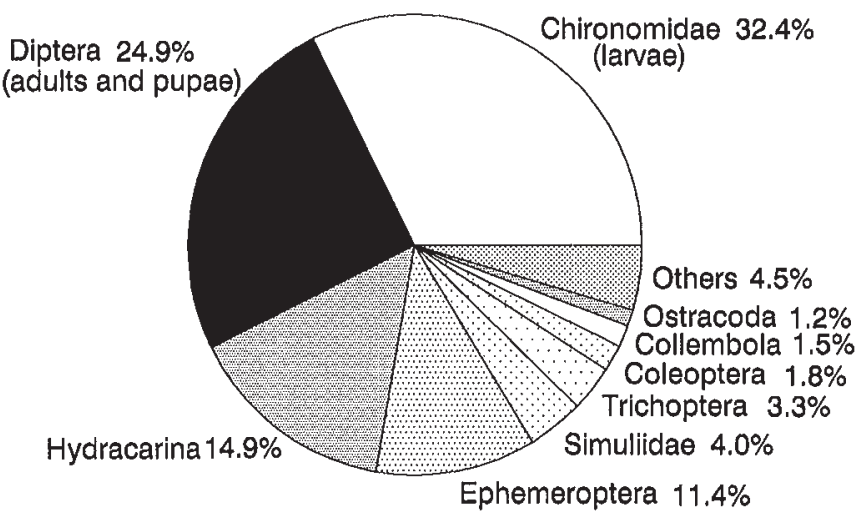

\section{(b) diet}

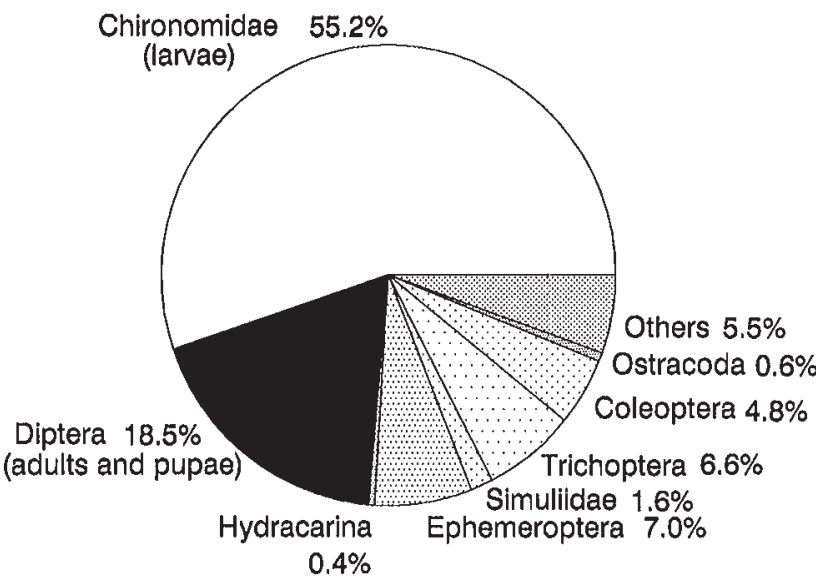

location where the fish normally held its snout. Substrate size was measured by placing two metre sticks parallel and perpendicular to the current, centred on the territory of each fish. We estimated the dominant substrate type (1: <2 mm; 2: 2-16 mm; 3: 17-64 mm; 4: 65-256 mm; 5: >256 mm in diameter) at 10-cm intervals (after Bain et al. 1985). The intervals were averaged to estimate substrate size for each territory.

\section{Analyses}

We used Spearman's rank correlation when data did not meet the assumptions required for parametric analyses. Otherwise, simple or partial parametric correlations were Pearson product-moment correlations. Predictive regressions were calculated using the ordinary least squares technique with $\log 10$ transformed data for body size measurements because allometric relationships are usually lognormally distributed (Harvey 1982). We also used $\log _{10}$-transformed data for current velocity and depth measurements because these variables also appear to be lognormally distributed. For some comparisons, we replotted arithmetic relationships from the literature on a logarithmic scale.

We estimated two morphological constraints that might limit the size range of prey that salmon can eat: gill raker spacing $(\mathrm{mm})=$ $0.115 \times$ fork length $(\mathrm{cm})$, and mouth width $(\mathrm{mm})=1.05 \times$ fork length (cm); both allometric relationships were measured by Wańkowski
Fig. 2. Spearman's rank correlation of percent composition of invertebrates in drift samples versus stomach contents in relation to body length for each of 46 juvenile Atlantic salmon by $(a)$ taxonomic categories (equation of curve is $Y=4.57 \log _{10} X-2.98 \log _{10} X^{2}-$ 2.74, $r^{2}=0.37, P<0.001$; where $Y$ is the rank correlation coefficient and $X$ is fish length) or (b) 0.1 -mm width categories (equation of curve is $Y=7.19 \log _{10} X-5.09 \log _{10} X^{2}-1.86, r^{2}=$ $0.61, P<0.001 ; X$ and $Y$ are as in $(a))$. Open circles represent rank correlations that are significant $(P<0.05)$ whereas closed circles represent rank correlations that are not significant $(P>0.05)$.
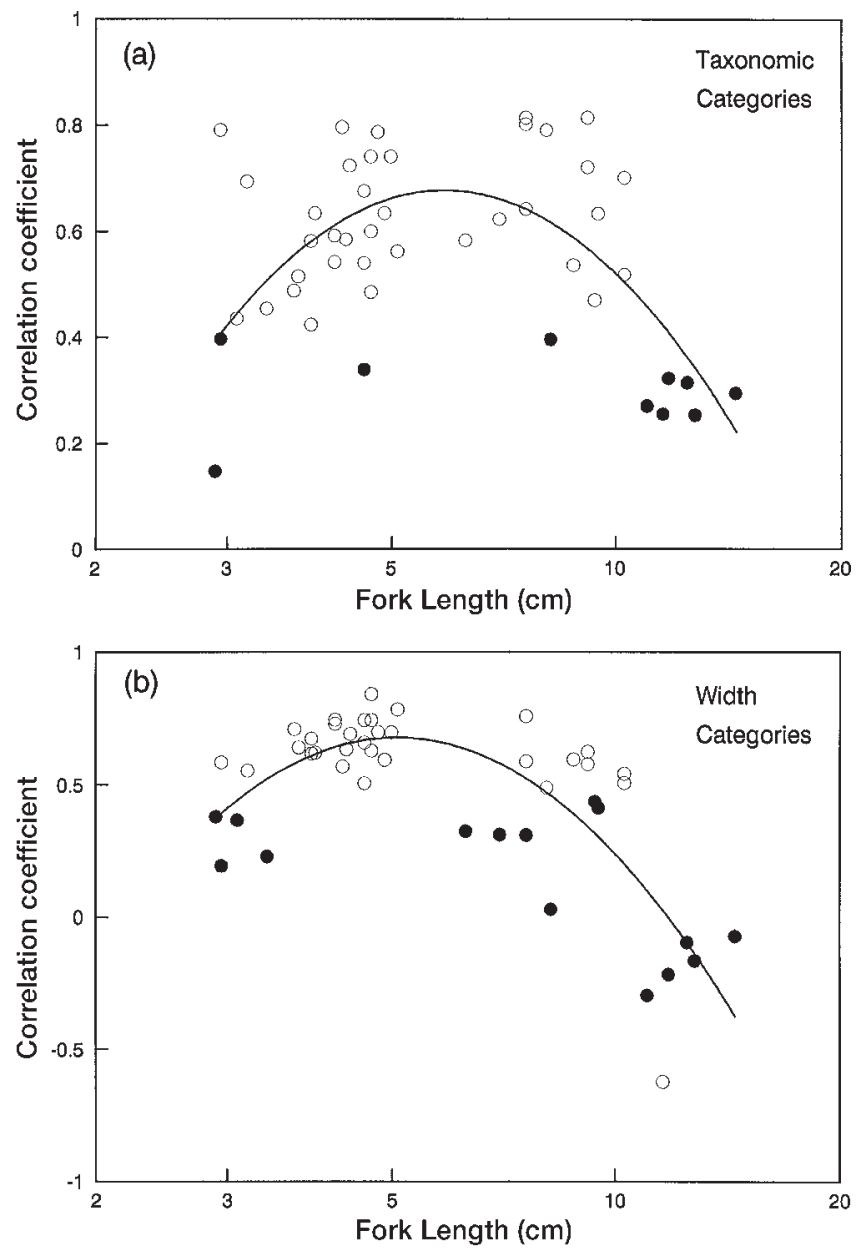

(1979). In addition, we estimated optimal prey size in two ways. First, we used Wańkowski's (1979) estimate of the prey width that maximized growth rate of Atlantic salmon: prey width $(\mathrm{mm})=0.26 \times$ fork length $(\mathrm{cm})$. Second, we used Bannon and Ringler's (1986) estimates of optimal prey width $(0.32 \times$ mouth width $)$ and length $(1.2 \times$ mouth width) that maximized energy gained per handling time for brown trout (Salmo trutta). To compare optimal prey size predicted by Bannon and Ringler's model as a function of fish length, we used Wańkowski's relationship for mouth width versus fork length to translate Bannon and Ringler's (1986) prediction as a function of fork length. Over our size range of fish, we calculated an optimum prey width $(\mathrm{mm})$ of $0.31 \times$ fork length $(\mathrm{cm})$ and an optimum prey length $(\mathrm{mm})$ of $1.15 \times$ fork length $(\mathrm{cm})$.

\section{Results}

Environmental correlates of invertebrate drift

A total of 5210 organisms were captured in the 461 -h drift 
Fig. 3. Relationship between average invertebrate width in stomach samples (solid circles and line; equation in Table 3) and in drift samples within the territory of that fish (open circles and broken line; $\log _{10}$ width $(\mathrm{mm})=-0.042 \log _{10}$ fork length $(\mathrm{cm})-0.39, r^{2}=$ $0.008, P=0.54$ ) versus fork length for 46 juvenile Atlantic salmon.

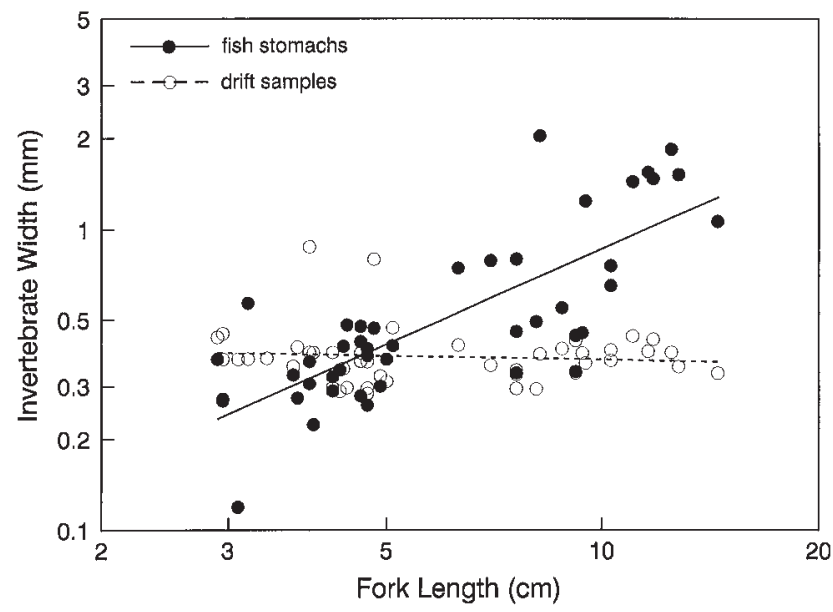

samples. The number of organisms in drift samples (108.5 \pm 85.4 (mean \pm SD), range 5-342) was positively correlated with increasing current velocity, water depth, and substrate size and negatively correlated with day of the year (Table 1). A partial correlation analysis indicated that drift abundance increased with increasing current velocity and water depth but decreased with day of the year (Table 1). Substrate size and the size of the juvenile salmon occupying the site sampled were not significant predictors of drift abundance after statistically controlling for the effect of other variables. The multiple regression model that best describes drift abundance is as follows: number of invertebrates $\left(\log _{10}\right.$ number $\left.\cdot \mathrm{m}^{-2} \cdot \mathrm{h}^{-1}\right)=$ $4.43+0.59 \log _{10}$ current velocity $\left(\mathrm{cm} \cdot \mathrm{s}^{-1}\right)+0.58 \log _{10}$ water depth $(\mathrm{cm})-0.012$ day of year $\left(r^{2}=0.66, P<0.001\right)$. The results of the partial correlation analysis were very similar when we used dry mass of drift samples as the dependent variable. The multiple regression that best describes dry mass of drift samples is as follows: dry mass $\left(\log _{10} \mathrm{mg} \cdot \mathrm{m}^{-2} \cdot \mathrm{h}^{-1}\right)=$ $3.67+0.56 \log _{10}$ current velocity $\left(\mathrm{cm} \cdot \mathrm{s}^{-1}\right)+0.41 \log _{10}$ water depth $(\mathrm{cm})-0.014$ day of the year $\left(r^{2}=0.63, P<0.001\right)$.

Despite a wide size range of invertebrates in the drift (width $0.39 \pm 0.11 \mathrm{~mm}$, range $0.04-5.58 \mathrm{~mm}$ ), none of the environmental variables was significantly correlated to the average width of prey in the drift samples (Table 1).

\section{Environmental correlates of diet}

A total of 1287 intact organisms were identified in the 46 stomach samples. The number of prey items found in the stomachs of individual fish (27.9 \pm 22.9 , range 3-134) was weakly related to day of the year and not significantly related to any environmental variable in a partial correlation analysis (Table 2).

The average width of prey items in stomach samples was positively correlated with current velocity, water depth, substrate size, and fish length (Table 2). However, larger fish use deeper, faster areas of the stream that have substrates of larger size (Keeley and Grant 1995). Hence, in a partial correlation analysis, only fish size was significantly related to mean prey size in stomachs (Table 2).

The average, maximum, and minimum size of prey in stomach samples increased with fish size (Table 3). All measures of prey size increased significantly with fish size except for minimum prey length (Table 3 ). Hence, we used prey width as our measure of prey size in subsequent analyses.

\section{Comparison of drift versus diet}

Invertebrates found in both the drift and stomach samples were dominated by a few taxa (Figs. $1 a$ and $1 b$ ). Larval chironomids and dipteran pupae and adults were the two most abundant taxa in both sample types. The most notable difference between the two sets of samples was the proportion of water mites (Hydracarina); they composed $14.9 \%$ of the drift samples but only $0.4 \%$ of the stomach samples.

The proportion of prey types found in the combined sample of 46 stomachs was positively correlated with their availability in the combined drift samples, whether we divided the invertebrates into taxonomic categories $\left(r_{\mathrm{s}}=0.56, n=31, P<0.01\right)$ or into $0.1-\mathrm{mm}$ width categories $\left(r_{\mathrm{s}}=0.70, n=20, P<0.01\right)$. However, because rare taxa may greatly influence the strength of such a relationship (Angradi and Griffith 1990), we repeated the analysis including only those taxa that composed at least $1 \%$ of the diet or the drift. Once again, the proportion of prey in the diet was positively correlated with the proportion of prey in the drift (taxonomic categories: $r_{\mathrm{s}}=0.64, n=17, P<0.01$; width categories: $\left.r_{\mathrm{s}}=0.78, n=16, P<0.01\right)$.

A comparison of the diet versus the drift for each fish suggests that diet selectivity was influenced by body size of the fish. The correlation between the proportion of invertebrates by taxa in the drift sample and the stomach sample was positive in all 46 cases and significantly positive in 36 cases (Fig. 2a). The strength of this positive correlation initially increased with increasing fish body size and then decreased for the largest fish (Fig. 2a). These changes in selectivity with body size were even stronger when the data were analyzed by body width category of invertebrate. There was a significant positive correlation between the proportion of invertebrates in the drift and diet in 30 of the 46 fish (Fig. 2b). Once again, the strength of this positive correlation initially increased with increasing body size and then decreased; the correlation was negative for fish larger than $10 \mathrm{~cm}$ in length and significantly negative for one fish. In summary, the smallest age $0+$ fish and the largest age $2+$ fish appeared to be the most selective foragers with respect to taxonomic category or size of invertebrate in their stomachs.

Overall, fish ate larger invertebrates than were found in drift samples (paired $t=3.17, n=46, P=0.003$ ). However, the degree of size selectivity was a function of the size of the fish. Small fish preyed selectively on small invertebrates whereas large fish preyed selectively on large invertebrates (Fig. 3). The difference between mean invertebrate width in the diet and drift increased with increasing body size (width difference $(\mathrm{mm})=0.113$ fork length $(\mathrm{cm})-0.516, n=46, r^{2}=0.57$, $P<0.001)$. The switch from negative size selectivity to positive size selectivity occurred at a body length of $4.6 \mathrm{~cm}$.

The degree of size selectivity was also related to prey type. Overall, the size of chironomid larvae in the diet and the drift did not differ significantly (paired $t=-0.32, n=41, P=0.75$; Fig. $4 a$ ). However, the proportion of chironomids in the diet 
Fig. 4. Frequency distributions of width of invertebrates in drift and stomach samples for $(a)$ chironomid larvae, $(b)$ dipteran pupae and adults, $(c)$ ephemeropteran larvae, and $(d)$ trichopteran larvae. Open bars represent frequency of invertebrates in drift samples and solid bars represent frequency in stomach samples.

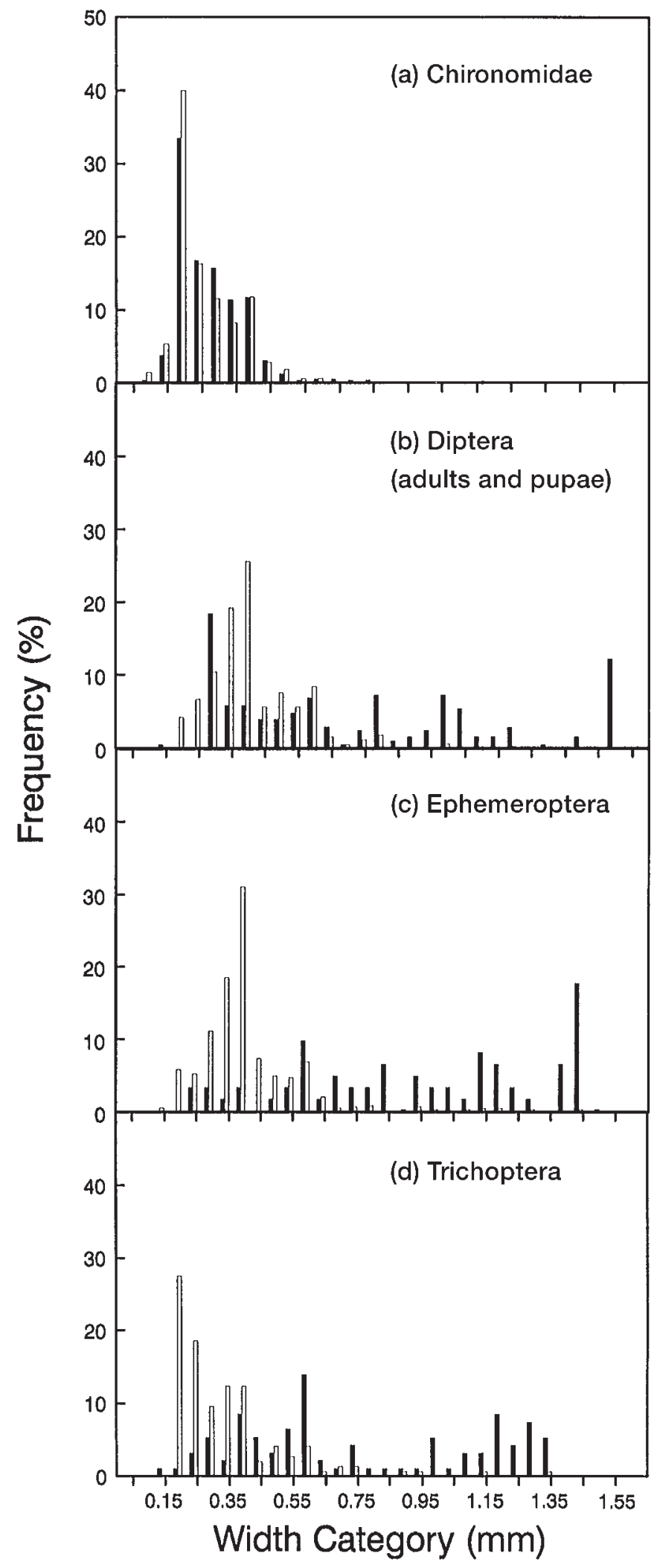

Fig. 5. The average frequency of the four most abundant taxonomic groups of invertebrates found in the stomachs of juvenile Atlantic salmon of six size categories.

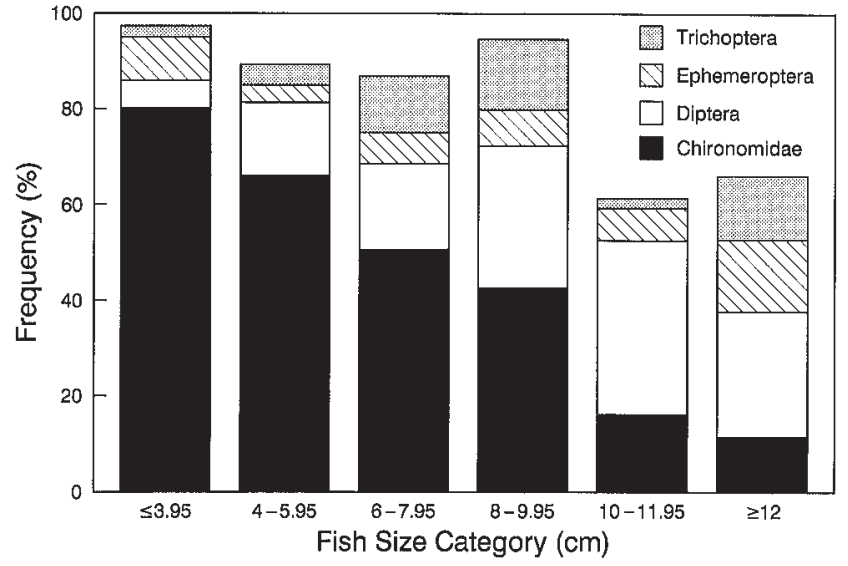

decreased with increasing body size of fish $(r=-0.75, P<$ 0.0001 ; Fig. 5), perhaps because chironomids were relatively small prey (Fig. 4). In contrast, the size of items in stomachs were larger than those in the drift for dipteran adults and pupae (paired $t=4.07, n=41, P=0.0002$; Fig. 4b), ephemeropterans (paired $t=6.14, n=25, P=0.0001$; Fig. $4 c$ ) and trichopterans (paired $t=5.45, n=19, P=0.0001$; Fig. $4 d$ ). The proportion of dipterans in the diet increased with body size $(r=0.52$, $P=0.0002)$, whereas the proportion of ephemeropterans $(r=$ $0.16, P=0.29)$ and trichopterans $(r=0.26, P=0.08)$ in the diet did not change significantly with body size (Fig. 5).

\section{Constraints on size selectivity}

The range of prey size in stomachs increased with increasing body size (Figs. $6 a$ and $6 b$ ), such that the difference between maximum and minimum prey size increased with fish length for both prey width $(r=0.76, n=46, P<0.001)$ or prey length $(r=0.68, n=46, P<0.001)$. Age $0+$ salmon (i.e., $\leq 5.1 \mathrm{~cm})$ ate most sizes of invertebrates that were available in the drift. They did not eat the largest or the smallest $5 \%$ of invertebrates. Fish longer than $10 \mathrm{~cm}$ ate the very largest invertebrates that were available but avoided small prey, primarily small chironomid larvae.

The optimal prey width predicted by Wańkowski (1979) and by Bannon and Ringler (1986) were about three times larger than the mean prey size in stomachs (Fig. $6 a$ ). The predicted optimal prey widths were similar to the observed maximum prey widths in stomach samples. The invertebrates available in the drift were much smaller than the mouth width of Atlantic salmon (Fig. 6a). Minimum prey length corresponded closely with gill raker spacing of Atlantic salmon (Fig. 6b).

\section{Discussion}

The abundance and dry mass of organisms in the drift increased with current velocity and decreased with day of the year. As in our study, current velocity is usually the best predictor of the abundance of drift flowing through a cross-sectional area of stream (Elliott 1970; Everest and Chapman 1972; Wańkowski and Thorpe 1979; Smith and Li 1983; Grant and Noakes 1987). Seasonal declines in the abundance of drift, 
Fig. 6. (a) Minimum (circles), mean (solid line), and maximum (triangles) prey widths in relation to the fork length of 46 juvenile Atlantic salmon. The dashed-dotted line represents the maximum prey widths predicted by mouth dimensions (Wańkowski 1979) and the dashed and short-dashed lines represent the optimal prey widths predicted by Bannon and Ringler (1986) and Wańkowski (1979), respectively. The shaded horizontal band represents the range of invertebrate widths found in 46 drift samples, excluding the uppermost $5 \%$ of maximum and the lowermost $5 \%$ of minimum invertebrate widths. (b) Minimum (circles), mean (solid line), and maximum (triangles) prey lengths in relation to the fork length of 46 juvenile Atlantic salmon. The dashed line represents the optimal prey lengths predicted by Bannon and Ringler (1986) and the dashed-dotted line represents the minimum prey length predicted by gill raker spacing (Wańkowski 1979). The shaded horizontal band is as in $(a)$ for invertebrate lengths.
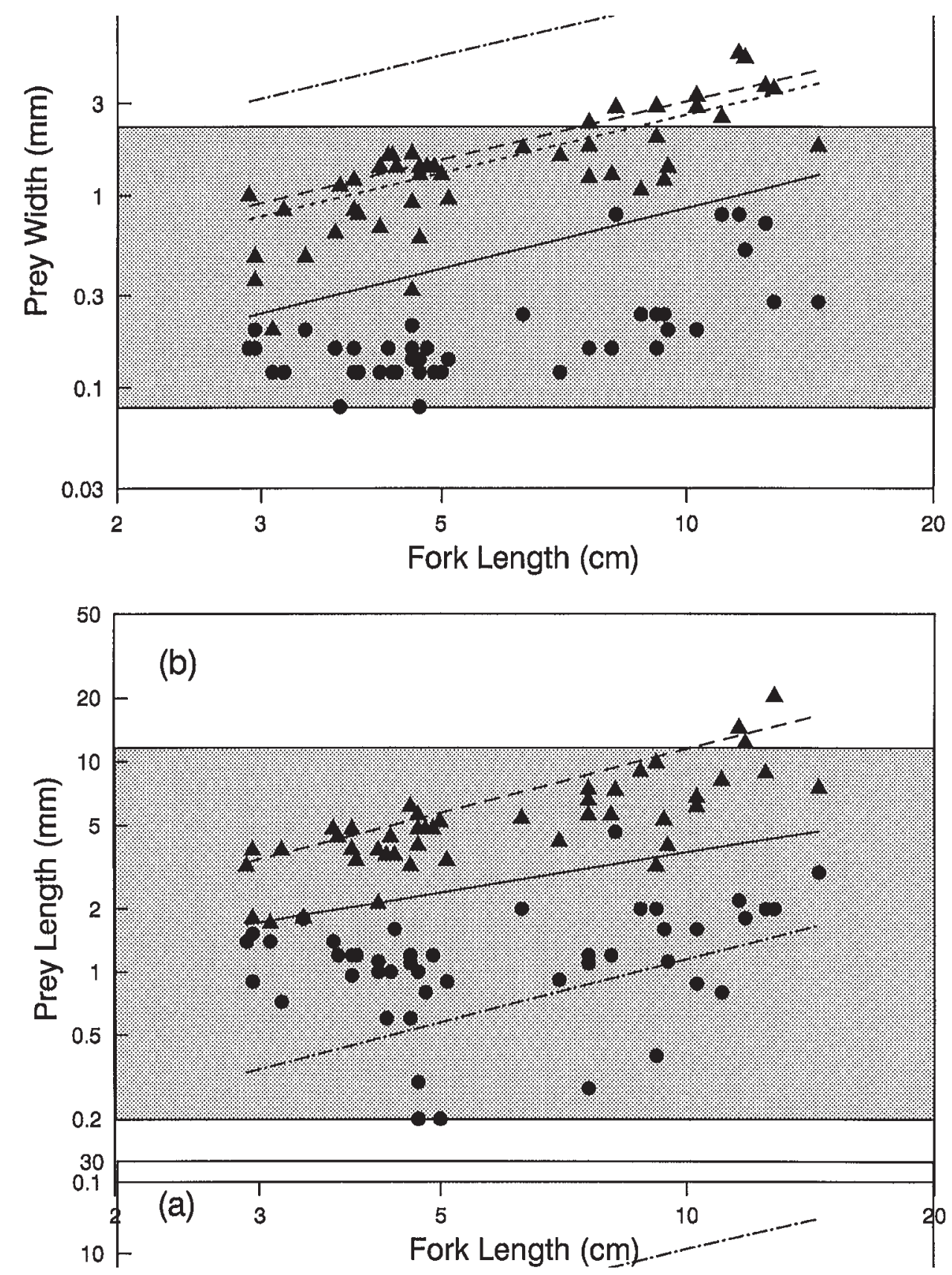

primarily due to the emergence of adult insects, are also common in other studies (Brittain and Eikeland 1988; but see Grant and Noakes 1987). The size of organisms in the drift was unrelated to any environmental variable we measured; Grant and Noakes (1987) found a similar result.

Larger fish ate larger prey in our study, as in many earlier 
Table 4. Spearman's rank correlations $\left(r_{\mathrm{s}}\right)$ of the proportion of prey types in the drift versus the diet for stream-dwelling salmonids.

\begin{tabular}{lccrl}
\hline Species & $r_{\mathrm{s}}$ & $P$ value & $n^{a}$ & \multicolumn{1}{c}{ Reference } \\
\hline Oncorhynchus clarki & 0.51 & $<0.2$ & 10 & Nakano et al. 1992 \\
Oncorhynchus mykiss & 0.81 & $<0.005$ & 11 & Angradi and Griffith 1990 \\
Oncorhynchus mykiss & 0.71 & $<0.1$ & 7 & Cada et al. 1987 \\
Oncorhynchus mykiss & 0.69 & $<0.2$ & 7 & Elliott 1973 \\
Oncorhynchus kisutch & -0.10 & 0.78 & 10 & Dunbrack 1992 \\
Oncorhynchus tshawytscha & 0.59 & $<0.05$ & 13 & Sagar and Glova 1987 \\
Oncorhynchus tshawytscha & 0.90 & $<0.002$ & 10 & Sagar and Glova 1988 \\
Salmo trutta & 0.79 & $<0.05$ & 7 & Cada et al. 1987 \\
Salmo trutta & 0.39 & $<0.5$ & 7 & Elliott 1973 \\
Salmo trutta & 0.49 & $<0.05$ & 17 & Glova et al. 1992 \\
Salvelinus confluentus & 0.39 & $<0.5$ & 11 & Nakano et al. 1992 \\
Salvelinus fontinalis & $0.46-0.68^{b}$ & $<0.05$ & 25 & Allan 1981 \\
Salvelinus fontinalis & $-0.25-0.69^{c}$ & $0.90-0.03$ & 10 & Grant and Noakes 1986 \\
Salvelinus fontinalis & 0.58 & $<0.05$ & 18 & McNicol et al. 1985 \\
Salvelinus leucomaenis & 0.86 & $<0.001$ & 13 & Furukawa-Tanaka 1985 \\
\hline
\end{tabular}

\footnotetext{
${ }^{a}$ Number of taxonomic categories in the comparison.

${ }^{b}$ Five separate sampling dates and comparisons.

${ }^{c}$ Four separate sampling dates and comparisons.
}

Fig. 7. Least-squares regressions of prey width $(\mathrm{mm})$ versus body length $(\mathrm{cm})$ for brook trout and rainbow trout (dotted line, arithmetic equation: $Y=0.30 X-0.25, r^{2}=0.95$; Rose 1986), brown trout (dashed line, arithmetic equation: $Y=0.289 X-0.363, r^{2}=0.83$; Fahy 1980 ), brook trout (dashed-dotted line, $\log _{10} Y=0.76 \log _{10} X-0.72, r^{2}=0.45$; J.W.A. Grant, unpublished data), and Atlantic salmon (solid line and circles, $\log _{10} Y=1.04 \log _{10} X-1.11, r^{2}=0.61$; this study).

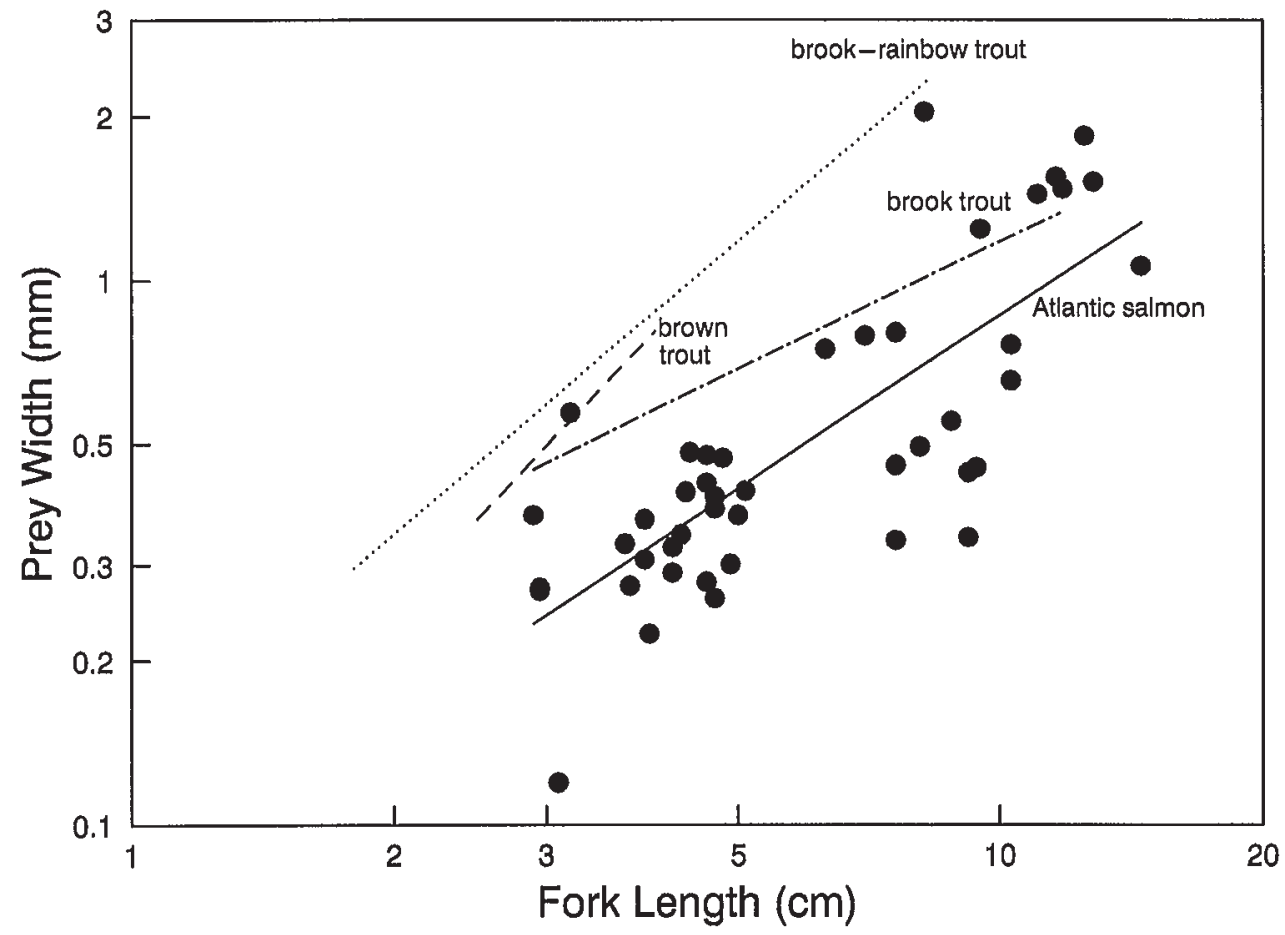

studies (Metz 1974; Newman and Waters 1984; Grant and Noakes 1986). Juvenile Atlantic salmon in Catamaran Brook primarily ate chironomid larvae, dipteran pupae and adults, and ephemeropteran and trichopteran larvae. These types of prey have also been reported in previous diet studies of juvenile Atlantic salmon (Allen 1941; Egglishaw 1967; Lillehammer 1973; Williams 1981; Thonney and Gibson 1989; Cunjak 1992).
Juvenile Atlantic salmon in Catamaran Brook fed opportunistically on all major types of invertebrates in the drift except for water mites. The similarity between the components of the drift and diet in our study has been noted in other studies of stream-dwelling salmonids (Table 4 ). Of the 22 correlation coefficients in Table 4, 19 were positive, and 12 were significantly so. In the three cases with negative correlations, the most abundant items in the drift, either water mites or ostracods, 
were rarely eaten (Dunbrack 1992; Grant and Noakes 1986). Other studies of Atlantic salmon (Egglishaw 1967) and coho salmon, Oncorhynchus kisutch (Dunbrack 1992) have also noted that water mites are not eaten. Water mites are often brightly coloured and may be unpalatable for fish (Kerfoot et al. 1980; Kerfoot 1982; but see Allan 1981).

Minimum, mean, and maximum prey size all increased with increasing body size of Atlantic salmon. However, the smallest and largest juveniles appeared to be the most selective foragers. Newly emerged young-of-the-year ate smaller prey than available in the drift, primarily small chironomid larvae, whereas large parr ate larger prey than available in the drift, primarily large dipteran pupae and adults.

Prey size selectivity in juvenile salmonids has often been linked to morphological constraints and to optimal prey size. Gill raker spacing was a good predictor of minimum prey length, supporting the hypothesis that morphological constraints set the lower limit of prey size ingested (Wańkowski 1979; Dunbrack and Dill 1983). Even if swallowed, age 2+ salmon may have been unable to retain small chironomids on their gill rakers. In contrast, the increase in mean prey size with body size probably had little to do with mouth size. Even newly emerged salmon should have been able to ingest about $95 \%$ of the available drift.

Feeding energetics may explain the increase in mean and maximum prey size with body size. Large prey contain more energy (Smock 1980) but take longer to handle (Bannon and Ringler 1986) than small prey. Salmon became increasingly size selective with body size, perhaps to maximize their net rate of energy gain. Despite this size-selective foraging, mean prey size in stomachs was much smaller than the optimum predicted by Wańkowski (1979) or Bannon and Ringler (1986). However, newly emerged parr appeared to prefer smaller prey than their predicted optimum. This discrepancy may result because the predicted optimal prey sizes are based on handling times for commercial pelleted food (Wańkowski 1979) and for crickets, Acheta domestica (Bannon and Ringler 1986). A resolution of this apparent discrepancy may require measuring the profitability (i.e., energy ingested per unit time) for each prey type and size in the drift.

Prey size versus body size relationships have been reported in three other studies of stream-dwelling salmonids. To compare these relationships, we replotted all four on a logarithmic scale; however, the original or arithmetic equations from Fahy (1980) and Rose (1986) are presented in the figure caption (Fig. 7). The allometric slopes for a combined brook trout (Salvelinus fontinalis) and rainbow trout (Oncorhynchus mykiss) regression (Rose 1986) and for a brown trout regression (Fahy 1980) were greater than the slope for Atlantic salmon (t $=-4.95, P<0.05$, and $t=-2.43, P<0.05$; for brook-rainbow trout regression and brown trout regression, respectively). However, the allometric slopes for Atlantic salmon and brook trout (J.W.A. Grant, unpublished data) regressions did not differ (ANCOVA, $\left.F_{1,119}=3.35, P=0.07\right)$. It was also clear that the Atlantic salmon in our study ate smaller prey than similarsized fish in the other studies. For example, the elevation of the brook trout regression was higher than the Atlantic salmon line (ANCOVA, $F_{1,119}=10.38, P=0.0016$ ). In addition, 45 of our 46 data points were below the brown trout regression (binomial test, $P<0.0001$ ) and all 46 data points were below the brook-rainbow trout regression (binomial test, $P<0.0001$ ).
The small size of the prey eaten by Atlantic salmon may be related to the fish's morphology or to the size distribution of invertebrates available in Catamaran Brook. Atlantic salmon parr have a smaller head, and perhaps a smaller gape, than brook, brown, or rainbow trout (Scott and Scott 1988). In addition, Atlantic salmon have more gill rakers than brown trout of a similar size (Hessen et al. 1988). Therefore, it is conceivable that Atlantic salmon may be limited by their morphology to eating smaller prey than the other species. However, three observations suggest that prey availability is a better explanation than morphological constraints for differences among the allometric relationships. First, based on mouth size (Wańkowski and Thorpe 1979), Atlantic salmon parr should have been able to eat the size of prey reported in Rose's (1986) study. Second, the marked differences between the two brook trout populations suggest environmental differences, such as the size of available prey. Third, the prey in Rose's (1986) study were not only larger but were taxonomically different from the prey in our study. For example, mayfly and stonefly nymphs composed a much larger proportion of the diet in his study than in our's. Given the opportunistic nature of salmonid foraging (Table 4), it seems likely that the size distribution of the drift in Rose's study was also larger than in our study.

In summary, juvenile Atlantic salmon were selective foragers, even though their diet resembled the taxonomic composition of the drift. Because of the small size of prey available, their diet was more likely constrained by gill raker spacing than by mouth size. The increasing size selectivity with increasing body size was likely due to salmon attempting to maximize their growth rate on prey of a relatively small size.

\section{Acknowledgements}

Financial support was provided by research grants from the Natural Sciences and Engineering Research Council of Canada (NSERC) and le Fonds pour la Formation de Chercheurs et l'Aide à la Recherche de Québec (FCAR) to J.W.A.G., by a research grant from NSERC to J.D. McPhail, and by a postgraduate scholarship from FCAR to E.R.K. Logistical support was provided by Dr. Rick Cunjak and the Catamaran Brook Habitat Research Project. We thank Sean Basquill for assistance in the laboratory and the field and Marten Koops for helpful discussions. The comments of R.A. Cunjak, J.S. Griffith, and an anonymous reviewer improved an earlier version of this work.

\section{References}

Allan, J.D. 1981. Determinants of diet of brook trout (Salvelinus fontinalis) in a mountain stream. Can. J. Fish. Aquat. Sci. 38: 184-192.

Allan, J.D. 1995. Stream ecology. Chapman \& Hall, London.

Allen, K.R. 1941. Studies of the early stages of the salmon (Salmo salar). 2. Feeding habits. J. Anim. Ecol. 10: 47- 76.

Angradi, T.R., and Griffith, J.S. 1990. Diel feeding chronology and diet selection of rainbow trout (Oncorhynchus mykiss) in the Henry's Fork of the Snake River, Idaho. Can. J. Fish. Aquat. Sci. 47: 199-209.

Bain, M.B., Finn, J.F., and Booke, H.E. 1985. Quantifying stream substrate for habitat analysis studies. North Am. J. Fish. Manage. 5: 499-506.

Bannon, E., and Ringler, N.H. 1986. Optimal prey size for stream 
resident brown trout (Salmo trutta): tests of predictive models. Can. J. Zool. 64: 704-713.

Brittain, J.E., and Eikeland, T.J. 1988. Invertebrate drift—a review. Hydrobiologia, 166: 77-93.

Cada, G.F., Loar, J.M., and Cox, D.K. 1987. Food and feeding preferences of rainbow and brown trout in southern Appalachian streams. Am. Midl. Nat. 117: 374-385.

Cunjak, R.A. 1992. Comparative feeding, growth, and movements of Atlantic salmon (Salmo salar) parr from riverine and estuarine environments. Ecol. Freshwater Fish, 1: 26-34.

Cunjak, R.A., Caissie, D., and El-Jabi, N. 1990. The Catamaran Brook habitat research project: description and general design of study. Can. Tech. Rep. Fish. Aquat. Sci. No. 1751.

Cunjak, R.A., Caissie, D., El-Jabi, N., Hardie, P., Conlon, J.H., Pollock, T.H., Giberson, D.J., and Komadina-Douthwright, S. 1993. The Catamaran Brook (New Brunswick) habitat research project: biological, physical and chemical conditions (1990-1992). Can. Tech. Rep. Fish. Aquat. Sci. No. 1914.

Dunbrack, R.L. 1992. Sub-surface feeding by coho salmon (Oncorhynchus kisutch Walbaum): a model and test. J. Fish Biol. 40: 455-464.

Dunbrack, R.L., and Dill, L. M. 1983. A model of size dependent surface feeding in a stream dwelling salmonid. Environ. Biol. Fishes, 8: 203-216.

Egglishaw, H.J. 1967. The food, growth and population structure of salmon and trout in two streams in the Scottish Highlands. Freshwater Salmon Fish. Res. No. 38.

Elliott, J.M. 1970. Methods of sampling invertebrate drift in running water. Ann. Limnol. 6: 133-159.

Elliott, J.M. 1973. The food of brown and rainbow trout (Salmo trutta and $S$. gairdneri) in relation to the abundance of drifting invertebrates in a mountain stream. Oecologia, 12: 329-347.

Everest, F.H., and Chapman, D.W. 1972. Habitat selection and spatial interaction by juvenile chinook salmon and steelhead trout in two Idaho streams. J. Fish. Res. Board Can. 29: 91-100.

Fahy, E. 1980. Prey selection by young trout fry (Salmo trutta). J. Zool. (London), 190: 27-37.

Field-Dodgson, M.S. 1985. A simple and efficient drift sampler. N.Z. J. Mar. Freshwater Res. 19: 167-172.

Furukawa-Tanaka, T. 1985. The ecology of salmonid fishes in Japanese mountain stream I. Food condition and feeding habit of Japanese charr, Salvelinus leucomaenis (Pallas). Jpn. J. Ecol. 35: 481-504.

Glova, G.J., Sagar, P.M., and Naslund, I. 1992. Interaction for food and space between populations of Galaxias vulgaris Stokell and juvenile Salmo trutta L. in a New Zealand stream. J. Fish Biol. 41: 909-925.

Grant, J.W.A., and Noakes, D.L.G. 1986. A test of a size-selective predation model with juvenile brook charr, Salvelinus fontinalis. J. Fish Biol. 29(Suppl. A): 15-23.

Grant, J.W.A., and Noakes, D.L.G. 1987. Movers and stayers: foraging tactics of young-of-the-year brook charr, Salvelinus fontinalis. J. Anim. Ecol. 56: 1001-1013.

Harvey, P.H. 1982. On rethinking allometry. J. Theor. Biol. 95: 37-41.

Hessen, D.O., Andersen, R., Hindar, K., and Skurdal, J. 1988. Food selection and competition in salmonids as reflected by gill-raker number and morphology. J. Appl. Ichthyol. 4: 121-129.

Keeley, E.R., and Grant, J.W.A. 1995. Allometric and environmental correlates of territory size in juvenile Atlantic salmon (Salmo salar). Can. J. Fish. Aquat. Sci. 52: 186-196.

Kerfoot, W.C. 1982. A question of taste: crypsis and warning coloration in freshwater zooplankton communities. Ecology, 63: 538-554.

Kerfoot, W.C., Kellogg, D.L., and Strickler, J.R. 1980. Visual observations of live zooplankters: evasion, escape, and chemical defenses. In Evolution and ecology of zooplankton communities.
Edited by W.C. Kerfoot. University Press of New England, Hanover, N.H. pp. 10-27.

Lillehammer, A. 1973. An investigation of the food of one- to fourmonth-old salmon fry (Salmo salar L.) in the River Suldalslågen, west Norway. Norw. J. Zool. 21: 17-24.

McNicol, R.E., Scherer, E., and Murkin, E.J. 1985. Quantitative field investigation of feeding and territorial behaviour of young-of-theyear brook charr, Salvelinus fontinalis. Environ. Biol. Fishes, 12: 219-229.

Merritt, R.W., and Cummins, K.W. 1984. An introduction to the aquatic insects of North America. 2nd ed. Kendall/Hunt, Dubuque, Iowa.

Metz, J.-P. 1974. Die invertebratendrift an der oberfläche eines voralpenflusses und ihre selektive ausnutzung durch die rengenbogenforellen (Salmo gairdneri). Oecologia, 14: 247-267.

Nakano, S., Fausch, K.D., Furukawa-Tanaka, T., Maekawa, K., and Kawanabe, H. 1992. Resource utilization by bull char and cutthroat trout in a mountain stream Montana, U.S.A. Jpn. J. Ichthyol. 39: 211-217.

Newman, R.M., and Waters, T.F. 1984. Size-selective predation on Gammarus pseudolimnaeus by trout and sculpins. Ecology, 65: $1535-1545$.

Pennak, R.W. 1978. Freshwater invertebrates of the United States. 2nd ed. Wiley, New York.

Randall, R.G. 1982. Emergence, population densities, and growth of salmon and trout fry in two New Brunswick streams. Can. J. Zool. 60: $2239-2244$.

Rose, G.A. 1986. Growth decline in subyearling brook trout (Salvelinus fontinalis) after emergence of rainbow trout (Salmo gairdneri). Can. J. Fish. Aquat. Sci. 43: 187-193.

Sagar, P.M., and Glova, G.J. 1987. Prey preferences of a riverine population of juvenile chinook salmon, Oncorhynchus tshawytscha. J. Fish Biol. 31: 661-673.

Sagar, P.M., and Glova, G.J. 1988. Diel feeding periodicity, daily ration and prey selection of a riverine population of juvenile chinook salmon, Oncorhynchus tshawytscha (Walbaum). J. Fish Biol. 33: 643-653.

Scott, W.B., and Scott, M.G. 1988. Atlantic fishes of Canada. Can. Bull. Fish. Aquat. Sci. No. 213.

Smith, J.J., and Li, H.W. 1983. Energetic factors influencing foraging tactics of juvenile steelhead trout, Salmo gairdneri. In Predators and prey in fishes. Edited by D.L.G. Noakes, D.G. Lindquist, G.S. Helfman, and J. Ward. Junk, The Hague. pp. 173-180.

Smock, L.A. 1980. Relationships between body size and biomass of aquatic insects. Freshwater Biol. 10: 375-383.

Thonney, J.-P., and Gibson, R.J. 1989. Feeding strategies of brook trout, Salvelinus fontinalis and juvenile Atlantic salmon, Salmo salar, in a Newfoundland river. Can. Field Nat. 103: 48-56.

Tippets, W.E., and Moyle, P.B. 1978. Epibenthic feeding by rainbow trout (Salmo gairdneri) in the McCloud River, California. J. Anim. Ecol. 47: 549-559.

Wańkowski, J.W.J. 1979. Morphological limitations, prey size selectivity, and growth response of juvenile Atlantic salmon, Salmo salar. J. Fish Biol. 14: 89-100.

Wańkowski, J.W.J., and Thorpe, J.E. 1979. Spatial distribution and feeding in Atlantic salmon, Salmo salar L., juveniles. J. Fish. Biol. 14: 239-247.

Werner, E.E., and Gilliam, J.F. 1984. The ontogenetic niche and species interactions in size-structured populations. Annu. Rev. Ecol. Syst. 15: 393-425.

Werner, E.E., and Hall, D.J. 1974. Optimal foraging and the size selection of prey by bluegill sunfish Lepomis macrochirus. Ecology, 55: 1042-1052.

Williams, D.D. 1981. The first diets of postemergent brook trout (Salvelinus fontinalis) and Atlantic salmon (Salmo salar) alevins in a Quebec river. Can. J. Fish. Aquat. Sci. 38: 765-771. 